О. О. Тслєжкіна

\title{
ПРЕЦЕДЕНТНІСТЬ МОВНО-ЕСТЕТИЧНИХ СИМВОЛІВ НАЦІОНАЛЬНОЇ КУЛЬТУРИ В ПОЕТИЧНОМУ МОВЛЕННІ ДМИТРА ПАВЛИЧКА
}

\footnotetext{
Тєлєжкіна О. О. Прецедентність мовно-естетичних символів національної культури в поетичному мовленні Дмитра Павличка.

У статті автор розглядає мовно-естетичні символи Сковорода, Франко, Шевченко, Тарас, Кобзар, Київ, Дніпро, Бабин Яр, верба, ужиті в поетичних творах Д. Павличка, як національно-прецедентні феномени, які є характерним складником лексичної системи поетичного мовлення митця.

Ключові слова: мовно-естетичний символ, поетичне мовлення, національно-прецедентний феномен.

(c) О. О. Тєлєжкіна, 2011.

$-678-$
} 
Тележкина О. А. Прецедентность языковых эстетических символов национальной культуры в поэтической речи Дмитрия Павлычко.

В статье автор рассматривает языковые эстетические символы Сковорода, Франко, Шевченко, Tapac, Кобзар, Київ, Дніпро, Бабин Яр, верба, используемые в поэтических произведениях Д. Павлычко, в качестве национально-прецедентных феноменов, которые являются характерной составляющей лексической системы поэтической речи автора.

Ключевые слова: языковой эстетический символ, поэтическая речь, национально-прецедентный феномен.

Telezhkina O.O. Precedentity of the language aesthetic symbols of the national culture in the poetic speech of D. Pavlychko.

The article deals with the language aesthetic symbols Skovoroda, Franko, Shevchenko, Taras, Kobzar, Kyiv, Dnipro, Babyn Yar, and pussy-willow used in the poetic works of D. Pavlychko. They are used as nationalprecedent phenomena that are characteristic constituent of the lexical system of the author's poetic speech.

Key words: language aesthetic symbol, poetic speech, national-precedent phenomenon.

Мовно-естетичні символи посідають особливе місце в культурі кожного народу, оскільки в їх основі лежить слово як універсальний засіб вираження світосприйняття людини. Такі слова функціонують за законами естетики, і відтак відіграють важливу роль у поетичному тексті як носії естетичної інформації. Характерні ознаки реалізації мовно-естетичних символів у художньому творі визначали такі вчені, як О. О. Потебня, М. М. Бахтін, Е. Кассірер, П. О. Флоренський. Зверталися до вивчення цієї проблеми і на початку XXI століття. Зокрема, О. О. Семенець розглядала лексеми символічного змісту у поезіях Євгена Маланюка, В. Ф. Півень схарактеризував мовно-естетичні знаки, ужиті у віршових творах Святослава Гординського. Незважаючи на важливість розробки цього питання для сучасної мовознавчої науки, дотепер не були досліджені лексеми-символи в поетичних творах Дмитра Павличка. Тим часом у його поезіях вони посідають значне місце як мовно-естетичні компоненти ідіолекту митця. Це й визначає актуальність звернення до аналізу особливостей реалізації мовно-естетичних символів у поезіях Д. Павличка.

Мета статті - схарактеризувати особливості функціонування мовноестетичних символів національної культури як прецедентних феноменів у поетичному мовленні Д. Павличка.

Спостереження за лексичним матеріалом поетичних збірок Д. Павличка довели, що поет активно вживає такі мовно-естетичні знаки, що стали символами із зародженням нової української літератури, їхній зміст зрозумілий кожному представникові української нації, і це дає всі підстави визначити їх як прецедентні феномени, оскільки, як стверджує О. О. Селіванова, «прецедентний феномен - це компонент знань, позначення та зміст якого добре відомі представникам певної етнокультурної спільноти, актуальний і використаний у когнітивному й комунікативному плані» [8, с. 591].

У віршах Д. Павличко, продовжуючи традиції Т. Г. Шевченка, А. С. Малишка, М. Т. Рильського, уживає такі мовно-естетичні знаки національної культури: 
а) символи-антропоніми: Сковорода, Шевченко, Кобзар, Тарас, Франко;

б) символи-топоніми: Київ, Дніпро, Бабин Яр;

в) фітосимволи: верба.

Ці слова-символи засвідчують єдність поета 3 рідним народом, вирізняють його як носія національної свідомості.

Приклади використання поетом аналізованих лексем засвідчуються вже в назвах віршів «Сковорода» [4, с. 291], "На відкритті пам'ятника T. Г. Шевченкові в селі Лозівиіі [4, с. 293], «Шевченкова верба» [5, с. 241], «Іван Франко» [4, с. 307; 5, с. 8] «Франкова криницяя [4, с. 302], «Київ» [6, с. 14]. Аналіз поетичних творів Д. Павличка довів, що використовувані митцем мовно-естетичні символи викликають у читача асоціації, пов'язані 3 Україною взагалі й українською культурою зокрема. Підтвердженням цього є зразки введення антропонімів Шевченко, Тарас, Кобзар у тканину поетичного твору. Автор розширює символічність значення імені Т.Г. Шевченка: це не лише поет-борець - символ одвічної боротьби українського народу за волю:

\section{Боялись Кобзаря пани,}

I підпанки, і яничари.

I двічі знищили дотла

Поета кам'яну подобу [4, с. 242],

не лише поет-пророк:

Єсть Украӥна вільна і могуча!

Ії святий Тарас, ї̈ пророк,

Стоїть спокійний на дніпровській кручі [4, с. 66].

У Д. Павличка Т. Г. Шевченко - символ стійкості у своїх політичних переконаннях, символ відданості рідній землі:

Запроданцям не йме Шевченко віри,

Йому чужий їх зрадницький сонет [4, с. 66],

це світоч духу і світової слави України:

Як армія, сила його розлилася,

Хоч він тут єдиний без карабіна.

І любить Куба свого Ніколаса,

Як любить тараса моя Україна [4, с. 338].

Наведені рядки доводять, що Тарас і Кобзар - це не просто слова (особове ім'я і назва особи за родом діяльності), а назви, пов'язані 3 людиною, що уособлює символ України, українства, українності.

Разом iз Т.Г.Шевченком прецедентним мовно-естетичним символом української національної культури, символом українського народу є І. Я. Франко. Іван Франко - втілення величі духу, «вогонь в одежі слова», який став духовним учителем не лише для Д. Павличка.

У Д. Павличка Іван Франко постає невтомним трудівником, який працює задля свого народу: 
Як Франко добував джерело

Волі, правди, науки -

Обливалося потом чоло,

Та не в'янули руки [4, с. 302]; символом правди i боротьби за справедливість, вірності рідному народу і віри в те, що в боротьбі і в житті живить тільки рідна земля і рідна історія, про що свідчать рядки з вірша «На етапі»:

Так топірець отой, залізом кутий,

Вернув Франкові силу й радість духа...

Згадав, як в Довбушевий час забутий

Боялися пани того обуха,

Що він стискав тепер в своїй правииі,

І вірив він, що знов огень забуха.

Тиранам не поможуть більш в'язнииі,

Бо весь народ - як хмара та грозова...

Ішов Франко вбирати блискавииі

В нетлінну у віках одежу слова! [4, с. 299]; символом вічності і незнищенності ідеї визволення рідної землі:

Я буду жити з тими, щзо на світі

Зруйнують пекло і збудують рай... -

Франко заснув, щоб встати у граніті

I подивитися на рідний край [4, с. 306].

Як і Т. Г. Шевченко, у віршах Д. Павличка І. Я. Франко - це пророк, який вів свій стражденний народ до світлого і вільного життя:

Там радощів квітуча сіножать,

Там ум ростин і пісня в кожній крові,

Там пам'яті народної лежать

Високі скиби в перегнилій крові.

І сорок літ ішов Франко-сіяч -

Стриміли руки колючками глоду,

І спів його звучав не раз як плач,

I плач його звучав як гімн народу [4, с. 310].

Для Д. Павличка імена цих велетів духу $\epsilon$ не лише осібно символічними. Розширюючи символічне значення імені Т. Шевченка й I. Франка, поет вкладає в них семантику єдності і неподільності. Вони виступають як символ єдності української держави, єдності їі східних і західних земель. Митець неодноразово звертається в поезіях до тандему Шевченко - Франко, про що свідчать рядки із творів «1939 рік» (а) і «Земле Шевченкова, земле Франкова» (б):

а) В одній землі, возз'єднаній, державній,

Шляхи Шевченка і шляхи Франка,

Не ділить рідних берегів ріка

Кривавою водою, наче ржа в ній [4, с. 105]; 
б) Земле Шевченкова, земле Франкова,

Ниво, засіяна щастям-добром,

Вічна твоя соловейкова мова,

Вічна розмова Дністра із Дніпром [4, с. 111].

Символічними є і топонімічні назви Київ і Дніпро, які поет сприймає як єдине неподільне ціле: Київ - «серце України», Дніпро - iï живодайна сила, без яких поет не мислить свого життя. Для митця, як і для кожного українця, немає Києва без Дніпра і неможливий Дніпро без Києва. Отож, Київ і Дніпро - це символ не лише серця України, це символ серця кожного українця. Правомірність висловленого ілюструють такі поетичні рядки:

а) Це щастя, як життя, одне й безкрає, -

І в тому знак його, що соние сяє,

Тече Диіпро, і Київ наш стоїть [5, с. 123];

б) І вийшов я на гори, як Хорив,

Поглянув на Дніпра важке свічадо,

Братам далеким поклонився радо,

Бо Київ разом з ними я творив [5, с. 151].

Символом горя українського i єврейського народів у поезіях Д. Павличка виступає топонім Бабин Яр, який без додаткових пояснень у кожного викликає спогади про трагічні події осені 1941 року:

Ходивши біля Бабиного Яру,

Де плаче вітер сивий, як пророк,

Я на червоний наступив листок,

Що з клена впав на плити тротуару.

I бризнула, як полум'я пожару,

Із нього кров і послизнувся крок,

Озвався кулемет, $і$ в темний змрок,

Неначе в яму, впав я від удару [5, с. 135].

В українській народній творчості засвідчується значна кількість символів, пов'язаних із назвами рослин. Д. Павличко як продовжувач народнопісенної традиції неодноразово використовує у віршах фітосимвол верба, який кваліфікується як мовно-естетичний знак української національної культури. Однак митець дещо відходить від фольклорного трактування - Без верби $i$ калини нема України. У поета органічно поєднуються символи верба і Шевченко (Тарас), не лише увиразнюючи звучання одне одного, а й підкреслюючи, що України немає не тільки без верби, але України немає і без Шевченка. Отже, верба - це Україна i Шевченко - Україна: Летіли ми на свято до Канади,

Везли з собою вутле деревие -

Тендітну правнучку верби тієі,

Що в Косаралі посадив Tарас [5, с. 241].

Те, що лексема верба належить до прецедентних мовно-естетичних символів національної культури, підтверджується iï здатністю утворювати 
похідні так само із символічним змістом, адже однією 3 основних рис мовно-естетичних знаків, $є$ їхня здатність продукувати трансформовані мовні форми, зберігаючи семантико-асоціативний стрижень слова [3, с. 359]. Свідченням того, що Д. Павличко поглиблює значення символічної лексеми i розширює можливості ऑii стилістичного використання є рядки із вірша «Шевченкова верба»:

Я брав на руки миле вербенятко,

Показував дитині з літака

Пасовища небесні, де лежали,

Немов корови, стада темних туч,

- Дивись, які дощуі розкішні будуть, -

Я заспокоював дочку пустель, -

Ти виростеш у Кобзаревім парку,

Ти затінок трудній душі даси.

Ти зашумиш над спраглими серияяи,

Ти вибухнеш, як смолоскип життя,

Весни й свободи, о моя вербичко,

О мій листочку, плеканий слізьми! [5, с. 241].

Усе це дозволяє зробити висновок про те, що мовно-естетичні знаки, пов'язані 3 іменами таких світочів української культури, як Сковорода, Шевченко (Тарас, Кобзар), Франко, та визначними місцями національної історії й культури - Киї, Дніпро, Бабин Яр, - а також традиційний фольклорний символ верба правомірно називати національнопрецедентними феноменами, оскільки їхнє значення зрозуміле кожному представнику української нації. Розглянуте засвідчує, що Д. Павличко розширює і поглиблює символічність значення названих мовно-естетичних знаків, підкреслюючи цим можливість їх ширшого використання.

Розглядувані символи є характерним складником лексичної системи поетичного мовлення Д. Павличка. Поет, який знає історію, перемоги, страждання i болі свого народу, який вихований на зразках культури i традицій свого народу, використовує у творах омріяні й закарбовані в його пам'яті імена, події, місця, предмети, що перетворилися на символи рідного народу. Усталені в народі символи стали для митця художніми образами, одиницями сконденсованого вияву його ідей і поглядів, засобом вираження й розкриття його поетичного Я. Продовженням розпочатого аналізу мовно-естетичних символів національної культури вбачаємо їх лексикографічний опис й укладання словника.

\section{Лiтература}

1. Єрмоленко С. С. Знакова культура мовної одиниці в комунікативно-епістемічній перспективі : автореф. дис. на здобуття наук. ступеня доктора філол. наук : спец. : 10.02.15 «Загальне мовознавство» / С. С. Єрмоленко. - К., 2007. - 32 с.

2. Єрмоленко С. Я. Мовно-естетичні знаки національної культури / Єрмоленко С. Я. // Язык и культура : Тезисы докладов на Третьей Международ. конф. - К. : ИМО Киевского ун-та им. Тараса Шевченко, Институт украинского языка НАН Украины, Фонд гуманитарного развития «COLLEGIUM», 1994. - C. $15-16$. 
3. Срмоленко С. Я. Нариси 3 історії української словесності. Стилістика і культура мови / С. Я. Срмоленко. - К. : Вища школа, 1999. - 431 с.

4. Павличко Д. Вибрані твори: у 2-х томах : [поезія] / Д. Павличко. - К.: Дніпро, 1979. - Т. 1. - 520 с. - (Першотвір).

5. Павличко Д. Вибрані твори: у 2-х томах : [поезія] / Д. Павличко. - К.: Дніпро, 1979. - Т. 2. - 480 с. - (Першотвір).

6. Павличко Д. Три строфи : [поезія] / Д. Павличко. - К. : Вид-во Соломії Павличко «Основи», 2007. - 128 с. - (Першотвір).

7. Півень В. Ф. Ідіостиль поетичних творів Святослава Гординського : дис. ... кандидата філол. наук : 10.02.01 / Півень Володимир Федорович. - Слов’янськ, 2007. - 198 с.

8. Селіванова О. О. Лінгвістична енциклопедія / О. О. Селіванова. - Полтава : Довкілля-К, 2010. - 844 с.

9. Семенець О. О. Лінгвістична синергетика ідіолекту Євгена Маланюка : дис. ... доктора філол. наук: 10.02.01 / Семенець Олена Олександрівна. - Кіровоград, 2005. - 504 с.

10. Семенець О. О. Символ як виразник специфіки ідіолекту письменника / О. О. Семенець // Наукові записки. Серія : Філологічні науки (мовознавство). - Вип. 30. - Кіровоград, 2000. - С. 109 - 120. 